SHAKSPERE'S SILENCES 
LONDON : HUMPHREY MILFORD

OXFORD UNIVERSITY PRESS 


\section{SHAKSPERE'S SILENCES}

By ALWIN THALER

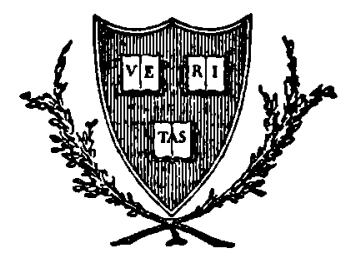

CAMBRIDGE, MASSACHUSETTS

HARVARD UNIVERSITY PRESS

I 929 
COPYRIGHT, 1929

BY THE PRESIDENT AND FELLOWS OF HARVARD COI.LEGE

PRINTED AT THE HARVARD UNIVERSITY PRESS

CAMBRIDGE, MASSACHUSETTS, U. S. A. 
Co the fflemory of MY FATHER AND MY MOTHER 
